
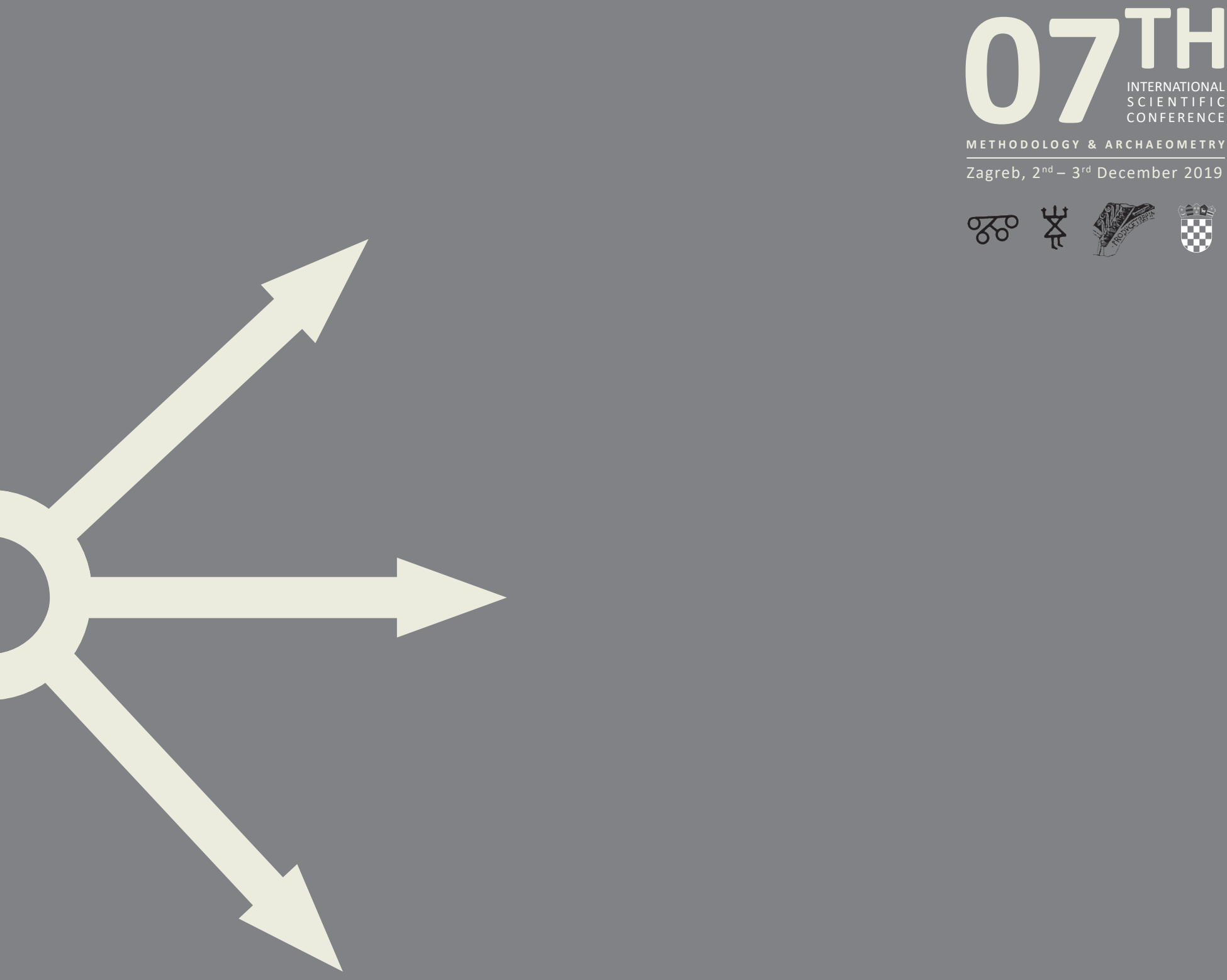
\%ㅇㅇ 岗

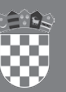
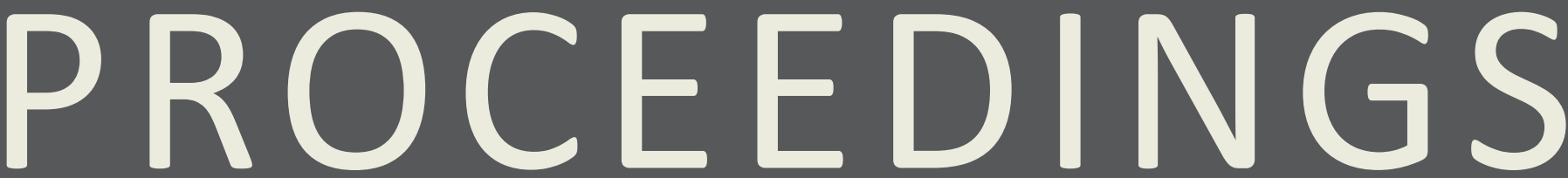

FROM THE $7^{\text {TH }}$ SCIENTIFIC CONFERENCE METHODOLOGY AND ARCHAEOMETRY 


\section{IMPRESSUM}

PUBLISHER

Faculty of Humanities and Social Sciences, University of Zagreb

FOR THE PUBLISHER

Miljenko Šimpraga

EDITOR

Ina Miloglav

Faculty of Humanities and Social Sciences, University of Zagreb

EDITORIAL BOARD

Predrag Novaković

Faculty of Arts, University of Ljubljana, Slovenia

Dimitrij Mlekuž

Faculty of Arts, University of Ljubljana

\& Centre for preventive archaeology, Ljubljana, Slovenia

Michela Spataro

The British Museum, London, United Kingdom

Duska Urem-Kotsou

Democritus University of Thrace, Komotini, Greece

Jasna Vuković

Faculty of Philosophy, University of Belgrade, Serbia

Rajna Šošić Klindžić

Faculty of Humanities and Social Sciences, University of Zagreb, Croatia

Jacqueline Balen

Archaeological Museum in Zagreb, Croatia

DESIGN \& DTP

Srećko Škrinjarić

All papers were reviewed in the peer review process in which the identity of both reviewers and authors, as well as their institutions, are respectfully concealed from both parties.

DOI

https://doi.org/10.17234/METARH.2020

ISSN 2718-2916

Faculty of Humanities and Social Sciences of the University of Zagreb

URL

https://openbooks.ffzg.unizg.hr/index.php/FFpress/catalog/series/MetArh http://www.ffzg.unizg.hr/metarh/

Publishing of this e-book is supported by

Ministry of Science and Education of the Republic of Croatia any medium or format, as long as they give appropriate credit, provide a link to the license, and indicate if changes were made. The content of this publication may not be used for commercial purposes. If the publication is remixed, transformed, or built 

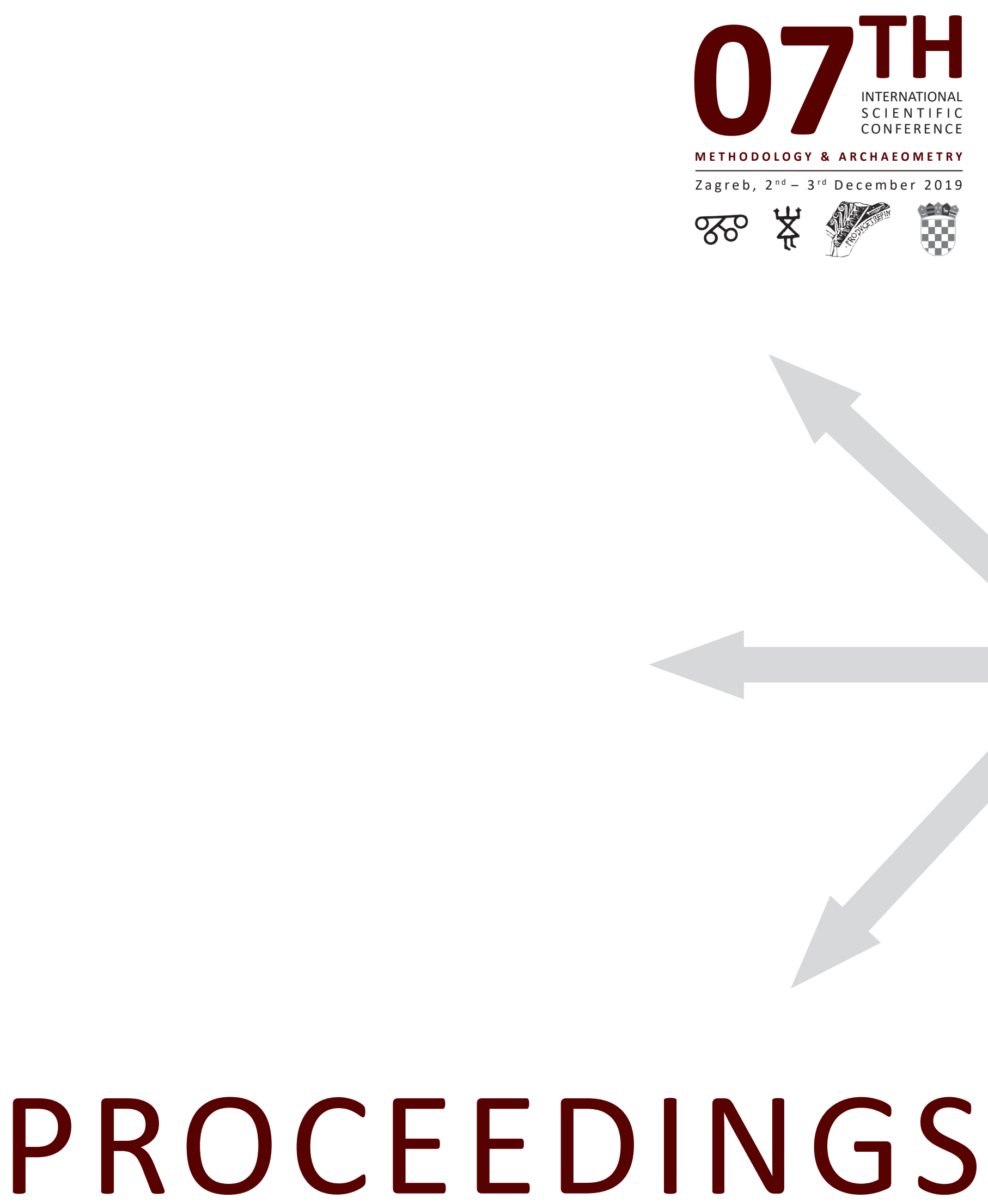

FROM THE $7^{\text {TH }}$ SCIENTIFIC CONFERENCE METHODOLOGY AND ARCHAEOMETRY 


\section{Content}

Ina Miloglav

Preface

Tamara Leskovar

09 Laboratory-based research on the changes caused to the in situ preserved archaeological remains by the heavy equipment compaction

Cornelius Meyer, Saša Kovačević, Daria Ložniak Dizdar, Mario Gavranović, Rajna Šošić-Klindžić, Tomislav Hršak, Marko Dizdar, Hrvoje Vulić, Boris Kratofil

Patterns everywhere: Geophysical prospection strategies at archaeological sites in Northern and Eastern Croatia

Domagoj Tončinić, Vinka Matijević, Miroslav Vuković

Image-based modeling approach in documenting Early Christian memorial chapel in Velić, Croatia

Esmeralda Agolli

A discussion on the theoretical and methodological ramifications of classification and typology of archaeological material: a Perspective from the Late Prehistoric Pottery (Albania)

Katarina Šprem

All aboard! Quarries and transport in Roman Istria 


\title{
Patterns everywhere: Geophysical prospection strategies at archaeological sites in Northern and Eastern Croatia
}

\author{
Cornelius Meyer, Saša Kovačević, Daria Ložniak Dizdar, Mario Gavranović,
} Rajna Šošić-Klindžić, Tomislav Hršak, Marko Dizdar, Hrvoje Vulić, Boris Kratofil

https://doi.org/10.17234/METARH.2020.03

\author{
Cornelius Meyer \\ cmprospection \\ Prenzlauer Allee 181 \\ DE - 10405 Berlin \\ cmp@cmprospection.com \\ Saša Kovačević \\ Institute of Archaeology \\ Gajeva 32 \\ HR - 10000 Zagreb \\ sasa.kovacevic@iarh.hr \\ Daria Ložniak Dizdar \\ Institute of Archaeology \\ Gajeva 32 \\ HR - 10000 Zagreb \\ daria-loznjak.dizdar@iarh.hr \\ Mario Gavranović \\ OREA - Institute for European and Oriental \\ Archaeology, \\ Austrian Academy of Science (ÖAW) \\ Hollandstrasse 11-13 \\ A - 1020 Vienna \\ mario.gavranovic@oeaw.ac.at
}

Rajna Šošić-Klindžić

University of Zagreb

Faculty of Humanities and Social Sciences

Department of Archaeology

Ivana Lučića 3

HR - 10000 Zagreb

rsosic@ffzg.hr

Tomislav Hršak Archaeological museum Osijek

Trg Sv. Trojstva 2

HR - 31000 Osijek tomislav.hrsak@amo.hr

Marko Dizdar Institute of Archaeology

Gajeva 32

HR - 10000 Zagreb marko.dizdar@iarh.hr

Hrvoje Vulić Municipal museum Vinkovci Trg Bana Josipa Šokćevića 16 HR - 32100 Vinkovci hrvoje@muzejvk.hr

Boris Kratofil Municipal museum Vinkovci Trg Bana Josipa Šokćevića 16

HR - 32100 Vinkovci boris@muzejvk.hr

Between 2014 and 2019 several geophysical prospection campaigns on archaeological sites in Northern and Eastern Croatia were realised. Survey layout, data and interpretation from the Hallstatt site of Jalžabet (Varaždin), from the Late Bronze Age and Iron Age site of Dolina (Nova Gradiška), and several prehistoric and Roman sites in Slavonia are presented and discussed in this paper. All data sets can be considered as incomplete since the investigations faced several serious 
constraints. Firstly, intensive agricultural use and small property sizes result in limited accessibility of the areas to be investigated. On no account a complete coverage of the site's cores was possible. Secondly, the limited budgets also implicate a methodological narrowness.

Do these resulting incomplete data sets contribute to increase our archaeological knowledge? From a purely scientific point of view, a total coverage not only of the "site" but also of the surrounding "landscape" is self-evident. In fact, archaeological fieldwork and research in today's "austerity societies" remain mere wishful thinking. Yet, couldn't we consider this kind of prospection campaigns as a full-value tool in archaeological research?

Due to the wide availability of multi-channel equipment, data collection has become a standard procedure during the last 15 years. By contrast, the archaeological interpretation of the data is a matter of permanent epistemological development. The combination of the mentioned incomplete data sets and poor documentation of archaeological information on historical excavations and surveys present a challenge for both archaeologists and geophysicists.

The presented examples prove that substantial archaeological information can be gathered even from limited data sets. Taking into account geological, geomorphological and archaeological information, prevents us from both, merely describing geophysical data as well as from over-interpreting. It is self-evident that all information is assembled and presented in GIS, so that continuous reworking of the data is possible for all involved parties.

Keywords: Magnetic prospection, geophysics, GIS, data interpretation, Croatian archaeology

\section{Introduction}

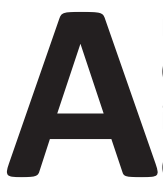
rchaeological sites in northern and eastern Croatia have been the subject of geophysical investigations for a long time, especially in the decades since 2000 several sites were more or less systematically surveyed. Neolithic sites, often located in the extensive alluvial plains are especially suitable for large-scale magnetic surveys (Botić 2017; Ložnjak Dizdar et al. 2017), while hillfort sites from Bronze Age, Roman sites such as military camps and settlements, and medieval sites require a wider methodological approach combining magnetic, GPR and geoelectric prospection (Mušič et al. 2013; Sekelj Ivančan and Mušič 2014).

Landscape conditions in the Pannonian basin, along the alluvial plains of the main rivers Mura, Drava, Sava, and the Danube offer very good conditions for large-scale geophysical prospection using multi-sensor equipments, as it has been the case with magnetic prospection for more than two decades. Less accessible sites, found in hilly and forested areas, demand more complex methodological approaches and the use of more flexible equipment. When dealing with stone architecture, then GPR and geoelectrical prospection are complementary methods to the magnetic survey or even alternatives (Mušič and Horn 2019).

Of the utmost importance in all prospecting projects is the archaeological interpretation of the data. It is crucial that the data sets only represent a small section of the soil parameters influenced by humans, and that they can only cover parts of archaeological landscapes. The first one is due to the methodology, the second to the fact that areas are not accessible because of agricultural use, forestation or lack of permits. Thus, all data sets, presented in this paper are to be considered as fragmentary data.

\section{Methodological remarks}

All presented data sets contain magnetic data since magnetic prospection was applied as a principal method. At one site, the Hallstatt burial mound of Jalžabet the GPR was used as a complementary method. At all other sites, a second and complementary method would have been recommendable, however, the prevailing circumstances did not permit for further prospection works.

\section{a) Magnetic prospection}

Magnetic anomalies are caused by changes in the complex magnetic properties of the soil. The amplitude of the magnetic anomalies is determined by the contrast between the different magnetic susceptibilities of archaeological structures and surrounding uninfluenced soil, as well as by the volume and depth of the magnetic structure. Two types of magnetisation can be observed at magnetic measurements: the induced and the remanent magnetisation. 
The induced magnetisation is ascribed to the effect that the elementary magnets of a matter are enhanced by external magnetic fields (e.g. the Earth's magnetic field), and, therefore, partly align with it. The magnetic susceptibility describes the propensity for this alignment, determining the strength of the enhancement of the magnetic field. The highest magnetic susceptibility values in soils are observed at ferromagnetic or ferrimagnetic minerals like the iron oxides magnetite and maghaemite. These minerals occur ubiquitously in the soil, forming microscopically small grains.

While the induced magnetisation requires an external magnetic field for its development, the remanent magnetisation stays fixed in a material after its creation. The most important type of magnetic remanence is caused by heating a material over its specific Curie temperature so that the elementary magnets become mobile and align with the external Earth's magnetic field. During the subsequent cooling, the alignment of the magnets is conserved and consequently, the burnt material becomes a strong magnet. Since the average Curie temperature of soil components is around $650^{\circ} \mathrm{C}$, fireplaces, kilns, layers of burnt daub and other burnt material, and accumulations of pottery can be detected on the base of this effect (Fassbinder 2017).

Another important magnetic phenomenon is diamagnetism. Structures mainly composed of diamagnetic materials, like quartz or calcite, cause noticeable negative anomalies. Diamagnetic materials literally repel the external magnetic field and form a strong magnetic field in the opposite direction, so that the resulting anomaly field has negative amplitudes. Based on this effect, buried constructions of limestone or sandstone, as well as fills of sand and calcareous sediments, can be identified in the magnetic data as anomalies with negative amplitudes of the magnetic gradient.

Figure 1. Fluxgate gradiometer array LEA MAX with 10 sensors during measurements at the prehistoric site of Dolina (Brod-Posavina county).

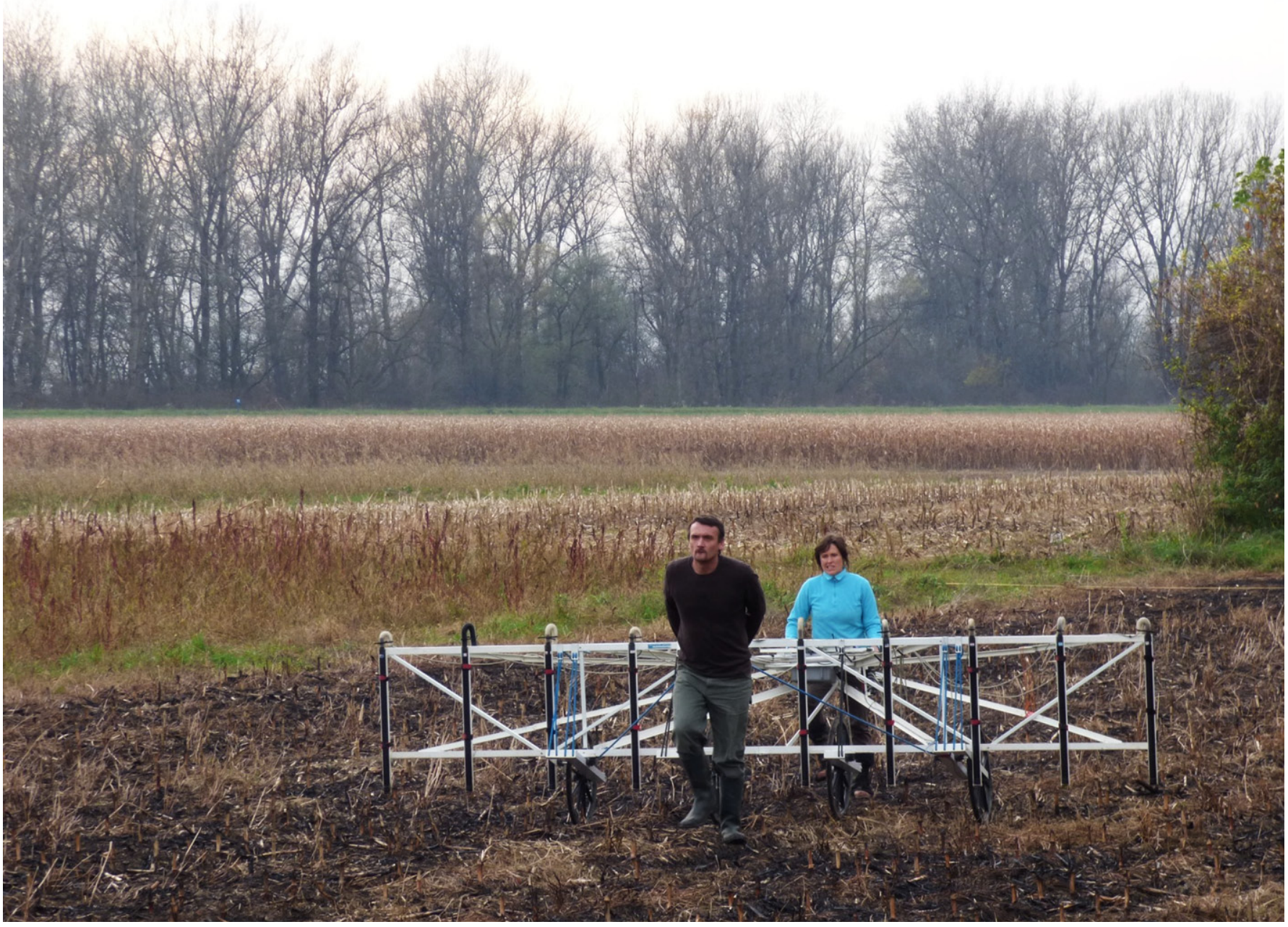


For the magnetic investigation, arrays of Förster fluxgate gradiometer probes mounted on a light and foldable cart were used (Fig. 1). Depending on the topographical and surface conditions of the investigated sites, there were taken between 5 and 10 fluxgate sensors. These gradiometer arrays are components of the convertible LEA MAX system (Zöllner et al. 2011).

The Förster FEREX fluxgate gradiometer probes register the vertical gradient of the vertical component of the Earth's magnetic field with an accuracy of $0.1 \mathrm{nT}$. The measured gradient (the difference between two vertically arranged sensors in a gradiometer probe) is insensitive to the typical large fluctuations of the Earth's magnetic field and is determined only by the magnetization of local anomalies in the ground (Schmidt 2009). The sensor separation and thus the profile distance was $0.5 \mathrm{~m}$.

The data positioning for the magnetic survey was realised by means of differential GPS, using two GNSS receivers NovAtel SMART V1 in RTK mode (Real-Time Kinematic) to achieve a relative accuracy of $2 \mathrm{~cm}$. The coordinate system in use during the magnetic measurements was UTM WGS84. When available, the coordinates of fixed points, located at the archaeological sites were used to correct the position of the base with the result that the absolute accuracy of the positioning reaches a level of $\pm 2 \mathrm{~cm}$. If no fixed points were available, the coordinates of the base were corrected by a RINEX data post-processing using the correction data of EUREF stations in Croatia. After data acquisition and processing, the results were re-projected into the project coordinate systems UTM ETRS89 or HTRS96 Croatia TM by means of the open-source Cartographic Projections library GDAL.
As a next step, the binary magnetic data were decoded and merged with the GPS data using a script-based decoding routine (ealdec). The actual data processing comprised of an offset and a drift correction of the data sets of each channel. Applying another script in an UNIX shell (ealmat), spike values were excluded from the correction. The maximum order of polygon fitting was set to the value of 2 . Subsequently, all decoded and corrected profiles were summed up into one single file. This file was subjected to a grid routine producing a Surfer7compatible grid with an equidistant mesh of $0.25 \mathrm{~m}$. At the end, this grid file was used to generate a GeoTIFF image, that can be projected into GIS projects and served as a base for the archaeological interpretation.

\section{b) Interpretation base}

Interpretation of geophysical data is more than just a description of measured values and their spatial distribution, or equalisation of measured values and archaeological features. In most cases, the data are interpreted qualitatively as many surveys are strictly non-invasive, which means that neither test excavations nor material sampling for laboratory testing are included. The reason for this, on the one hand, is the limited means and capacities and, on the other hand, the high quality of qualitative interpretations, which, according to experience, serve as a solid basis for further work such as excavations. Thus, the interpretation drawings display the result of an approach that combines the knowledge of physical properties of the soil with the descriptive and comparative methods of archaeological interpretation (Neubauer and Eder-Hinterleitner 1997; Meyer 2013).

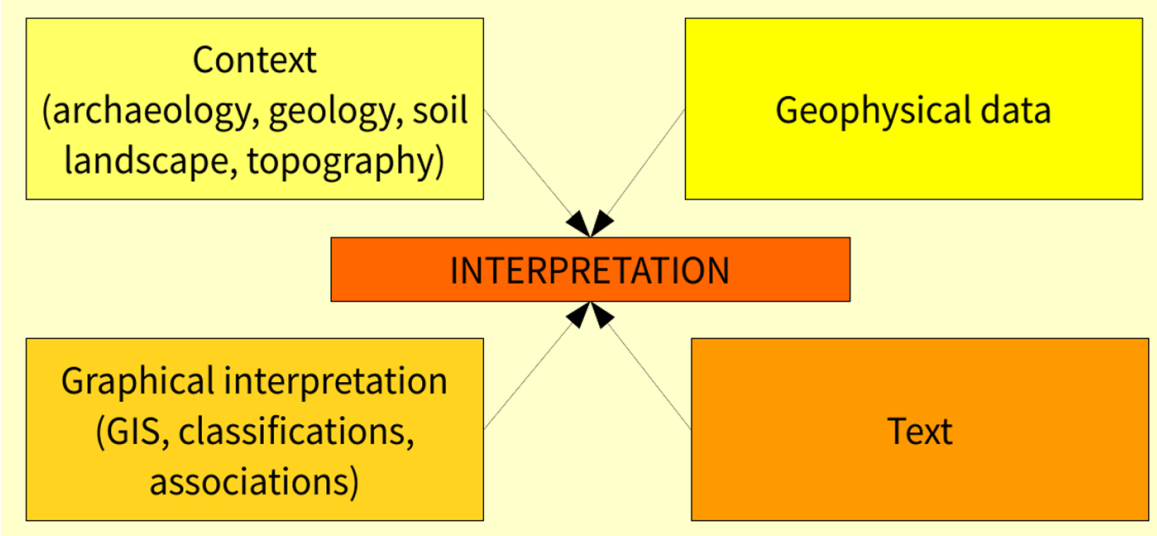

Figure 2. Scheme for interpretation of geophysical data from archaeological sites. 
Needless to say that the precarious character of any qualitative and comparative interpretation has to be taken into account since the reading of geophysical data can evermore be subject to new or evolving hypotheses and knowledge.

The minimum requirements for the interpretation of geophysical data in archaeology include both, a georeferenced graphical and a descriptive part which does not only repeat the graphical interpretation, but it also includes an evaluation of the chosen methodology, considerations on the certainty and the plausibility of the interpretation (Fig. 2).

Since the majority of the data comes from magnetic surveys, the basis for interpretation is explained more detailed here only for magnetic data. For more specific insights into the interpretation of GPR data see Conyers 2012, for example.

The general approach to classify the magnetic anomalies is to distinguish them respectively by means of their amplitudes, polarisation and shape. Secondly, the spatial distribution, geometric patterns and spatial interrelationships of anomalies and their clusters were taken into account in the interpretation. Of course, comparative observations of similar archaeological sites and the data obtained there, were of crucial importance to check the archaeological plausibility of the interpretation.

As part of the first step, anomalies of unambiguously modern and thus archaeologically irrelevant origin, in most cases indicating ferromagnetic objects, are separated and marked. Magnetic anomalies of modern ferromagnetic objects usually show very high amplitudes of the $Z$ component of the vertical gradient. Depending on size, distance from the sensor and magnetisation, they can reach several hundred Nanotesla. Moreover, these anomalies mostly have a clear dipole character. Especially, wire fences, electricity poles and scrap metal deposits cause anomaly patterns of strong amplitudes and alternating polarisation. In the case of surveys on agricultural land, it is furthermore required that linear anomalies with both positive and negative polarisation, that could be associated with traces of agricultural processing such as ploughing have to be identified by comparison with field observations in order to avoid misinterpretation of linear structures. Especially, the typical small plot size, observed in large parts of Slavonia, can cause a high density of these agricultural magnetic anomalies.

The next step is to sort the remaining anomalies that were assumed to have an archaeological or geomorpho- logical background. In order to structure these anomalies, several classes are introduced with corresponding causal physical structures.

Since the predominant natural rocks in Northern and Eastern Croatia are Neogene limestones and sandstones, it can be assumed, that these materials are also found at archaeological sites as a construction material. Quartz and calcite, the minerals forming these rocks are diamagnetic matters, i.e. they repel the external magnetic field and cause negative magnetic anomalies. For this reason, negative anomalies in a linear arrangement can usually be associated with foundation remains. The plausibility of these assumptions can be checked by mapping wall remains visible on the surface, identifying the right angles and comparing the position of the assumed structures with the topographic situation. However, it is also possible that the limestones and sandstones with accompanying minerals show a superposition of diamagnetic, paramagnetic and ferromagnetic effects, resulting in diffuse anomaly patterns with very weak amplitudes. This may explain some difficulties in the identification of ancient construction remains in magnetic data of the region, as well as provides the justification for using the GPR or geoelectrics as complementary methods.

Negative anomalies of less strict geometric appearance also originate at accumulations of predominantly diamagnetic material, found at backfills of sand or calcareous material. These backfills may refer to ramparts or remains of prehistoric or ancient excavation works. Eventually, negative anomalies are observed at negative, i.e. excavated structures which were refilled shortly after. In these cases, the material mixture, although chemically identical to the surrounding soil, causes the original magnetization, the sum of induced and remanent magnetization, to be reduced by the remanent part, which disappears when the material is randomly mixed (Fassbinder 2015).

Besides firm construction remains, other archaeological features can be identified in magnetic data. Firstly, circular, ellipsoid and rectangular positive anomalies with low to moderate amplitudes (in the range of 1 to $10 \mathrm{nT}$ ) and extensions between 1 and a few meters often can be attributed to pit fillings. These features can reflect the positions of construction pits in relation to the building remains, working and storage pits and burials on necropoleis. A detailed archaeological interpretation of these type of anomalies is only possible under consideration of their spatial archaeological context. The weak positive values of the magnetic gradient origin in an increased 


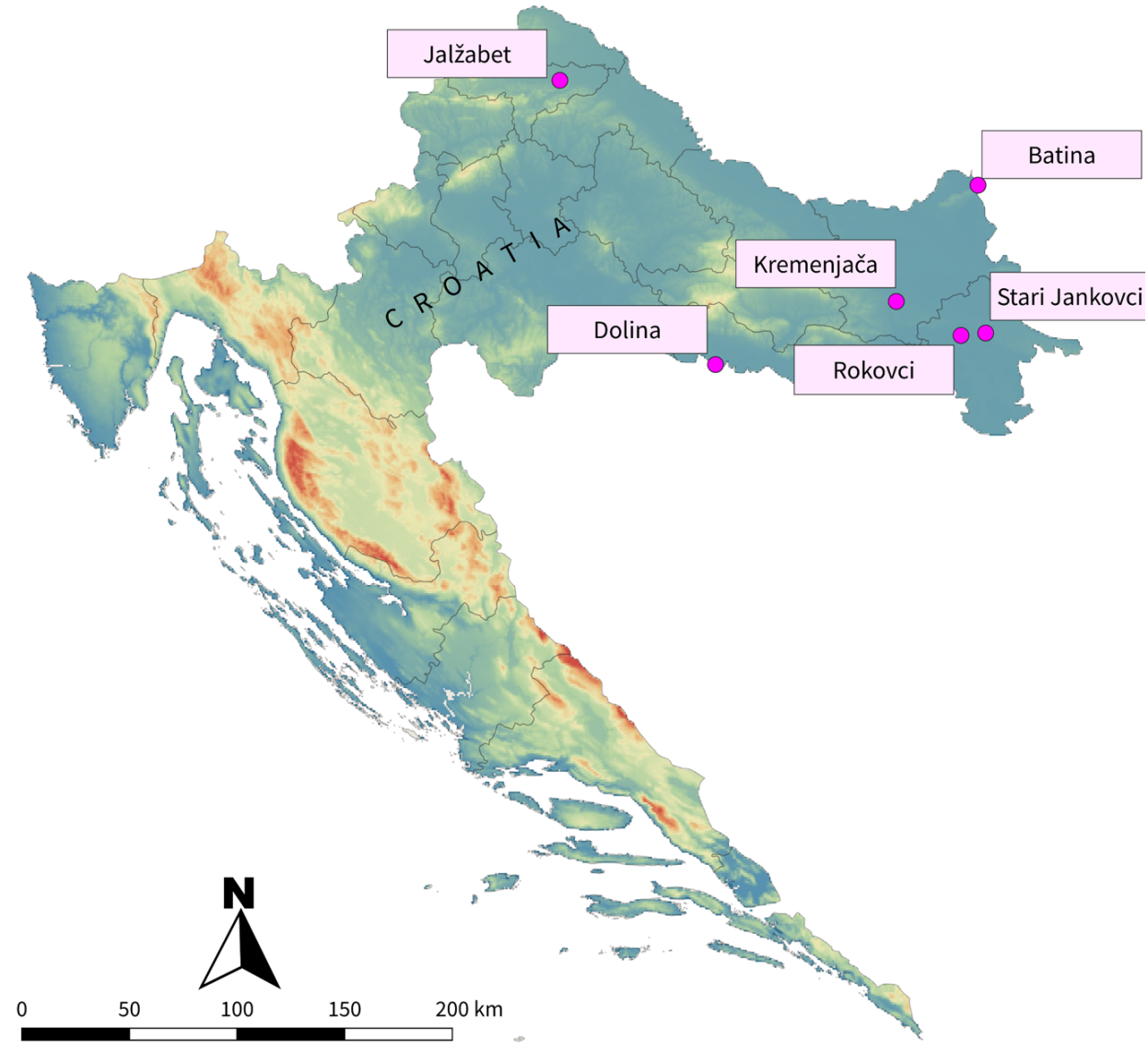

Figure 3. Location of the men tioned sites in Northern and Eastern Croatia.

magnetisation, where both, induced and remanent magnetisation occur. The induced magnetisation is caused by an increased content of ferrimagnetic iron oxides in the pit fillings. That is an effect of conversion of low magnetised iron oxides into ferrimagnetic oxides such as maghaemite and magnetite in combustion processes and by microbiotic influence (Fassbinder 2017). In addition, anomaly patterns which are associated with ditch fillings show the similar amplitude and polarisation characteristics with linear geometry.

Furthermore, clearly recognisable magnetic dipole anomalies with medium amplitudes and north-south orientation of the dipoles usually occur in magnetic data of archaeological sites. In fact, all magnetic anomalies are composed of magnetic dipoles, but in gradiometer data, measured at a short distance from the magnetised objects and materials, only the magnetic anomalies of higher magnetised objects appear as recognizable dipoles. If these dipole anomalies, under the assumption that they do not reflect modern effects, are arranged in clusters or are found inside of assumed buildings and in their surroundings, respectively, they can be considered as accumulations of predominantly thermoremanent material indicating remains of furnaces, hearths or other human-made fireplaces. Features of this type have been observed and described at numerous archaeological sites (Aitken 1970; Linford and Canti 2001, for example).

Eventually, magnetic anomalies reflecting natural structures and features can also be identified in most data sets. Elongated or extensive zones with apparently irregular order of positive and dipole anomalies often correlate with bedrock outcrops, silted-up water courses and other geomorphological structures. The prevailing complex anomaly patterns depend on the material properties of rocks and soil minerals and layer thickness.

Another class of natural effects are magnetic anomalies coming from lightning strikes. Amplitudes and polarisation are often similar to magnetic anomalies from remains of ovens, however, they lack the archaeological context and are found at highly exposed places. Depending on the geological conditions, these anomalies have a dipole or multi-pole character and very variable shapes, including long curved lines or butterfly shapes (Jones and Maki 2005). 
All anomaly classes described are presented in different colours and hatchings in the interpretation drawings (see legends). For reasons of clarity, the anomalies of modern origin are not displayed on some of the interpretation maps.

\section{Overview of the described sites and surveys}

Of the more than 30 sites investigated since 2014, 6 are presented in this paper (Fig. 3): Magnetic prospection and a GPR survey were carried out at the Hallstatt site of Jalžabet (Varaždin county) during two campaigns in 2016 and 2019. The Late Bronze Age and Early Iron Age site of Dolina (Brod-Posavina county) was investigated by magnetic measurements in 2014. Since 2018 magnetic prospection works have been carried out at the Neolithic site of Kremenjača near Gorjani (Osijek-Baranja county). A total of 4 survey days since autumn 2018 and an area of 20 ha has been investigated. The prehistoric and Roman necropoleis of Gradac and Sredno, located on the loess ridge of Bansko brdo in the archaeological landscape of Batina (Osijek-Baranja county) were surveyed by means of magnetic prospection in autumn 2016. The case study of Stari Jankovci (Vukovar-Srijem county), also from autumn 2016, is an example of a targeted investigation of an assumed burial mound that resulted in containing a major Roman burial. The half dozen case studies are completed by the investigations in the surroundings of the medieval site of Rokovačke zidine (Vukovar-Srijem county), realised in March 2018. The total area of all surveys is about 53 hectares.

\section{The Hallstatt site of Jalžabet (Varaždin county)}

The Early Iron Age site of Jalžabet was subjected to two geophysical prospection campaigns using both, magnetic prospection and GPR surveys.

The site of Jalžabet is located at the southern rim of the Drava valley, $18 \mathrm{~km}$ to the southeast of Varaždin. It is situated in the contact zone between the tertiary hills in the South crossed by water courses flowing into the Drava and the river plain. The plains are covered by thick layers of alluvial sediments. On the slopes, there can be expected colluvial soils and older river terraces.

The site with the striking Early Iron Age burial mound of Gomila belongs to a large prehistoric landscape, characterised by settlements and necropoleis. The entire area can be assumed to have a diachronic stratigraphy, which is partly confirmed by the results from excavations. Many smaller elevations have been identified so far by the use of LiDAR data and field surveys. However, it has to be suspected, that the majority of the burial mounds are almost completely flattened (Šimek and Kovačević 2014).

Archaeological investigations at a flattened mound, called "Hügel II" revealed a complex funerary monument, comprising a pebble-paved plateau, a rectangular burial chamber of stones, and dromos marked by stones. Small finds in large numbers and the organic remains found in the originally wooden funerary chamber proved the cremation of a horse (Šimek 1998). Under consideration of the results of the geophysical survey of 2016, a largescale excavation started at the burial mound of Gomila in September of 2017 (Kovačević 2018).

The geophysical investigations were effectuated in the surroundings of the burial mound of Gomila and on the mound itself. In autumn 2016, an area of about 4 hectares was measured, located on isolated fields around the mound. Further measurements were impeded by the inaccessibility of the field due to crops. Thus, the second campaign was projected for the spring season and realised in March of 2019. Then almost 10 hectares of ploughed fields were investigated. Partly, the gradiometer array had to be carried by hand, which slowed down the fieldwork. Nevertheless, it was still possible to survey about 3 hectares per day. Additional GPR measurements were applied on a smaller part of the plateau of the Gomila tumulus in order to obtain a better database for the interpretation of the expected funerary structures inside the mound.

The aim of the investigation was to work towards a clearer understanding of the overall setting of the assumed prehistoric landscape around the Gomila tumulus. The magnetic data from the immediate surroundings of the tumulus prove the existence of a ditch system with at least one entrance and probably a stone row outside the ditch. Possible sites of flattened tumuli were identified in the area to the northeast of the Gomila tumulus. The correlation between terrain and the prehistoric structures becomes visible in two, North-South running extensive ditch systems, framing the Gomila and a larger area of the settlement remains. The combination of magnetic and GPR data from the tumulus revealed many details including the rough dimensions of the burial chamber and information on the preservation status of the burial. The stone rows found around the burial chamber reflect as negative magnetic anomalies and as highly reflective zones in the GPR data, respectively. Direct verification of 


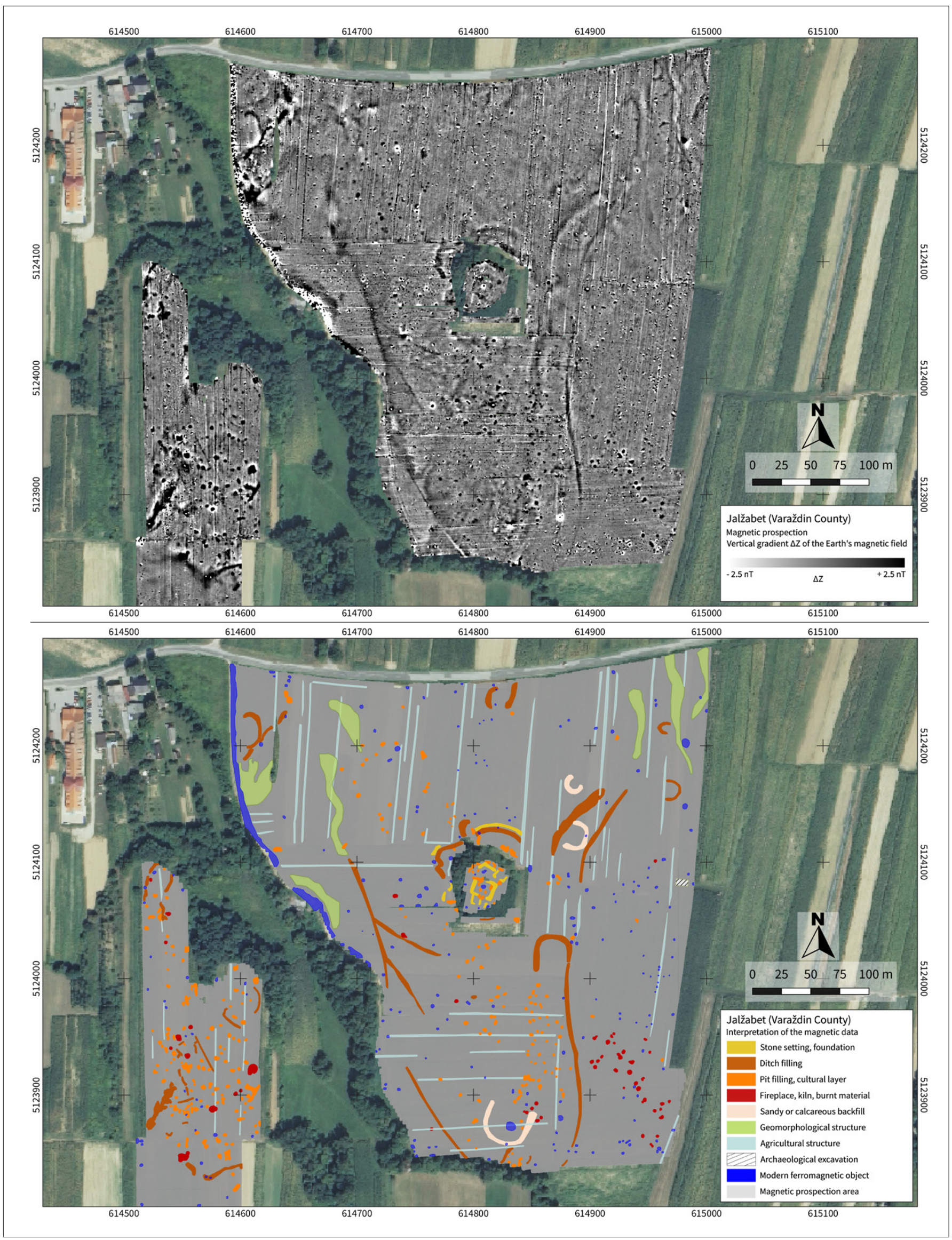

Figure 4. Jalžabet: Magnetic data and archaeological interpretation (Coordinate system: WGS 84 UTM zone 33 North, EPSG: 32633 , orthophoto: geoportal.dgu.hr). 
the burial chamber was not possible due to modern contamination in the central part of the plateau. Magnetic data and their interpretation are presented in Figure 4. Nevertheless, future archaeological research and additional geophysical surveys are strongly recommended for verifying the observations derived from the data and to clear up the temporal and spatial relations between the different archaeological structures.

\section{The Late Bronze Age and Iron Age site of Dolina (Brod-Posavina county)}

In November 2014 magnetic measurements were carried out on the prehistoric site of Dolina (Brod-Posavina county) on the northern bank of the Sava river. The objectives were to prove the existence of presumed Late Bronze Age and Iron Age settlements and to explore their internal structure. The measurements were carried out at two sites with surface finds that suggested settlement remains in the soil. At the western site, an area of 2.6 hectares was investigated, at the eastern site an area of 2.9 hectares. In addition, magnetic measurements were carried out north of the settlement on the area of the prehistoric necropolis of Glavičice with a total of 4.6 hectares.

The site is located on the northern terraces of the Sava river. In this area, alluvial forests alternate with agricultural land, mainly grassland and cornfields. Therefore, the magnetic measurements had to be limited to the grassland areas and the harvested fields.

Lithologically, the Sava floodplain is characterised by Pleistocene and Holocene sediments of the Pannonian Basin. Due to periodic flooding, hydromorphic soils such as Pseudogley dominate (Vidaček et al. 2001). This soil

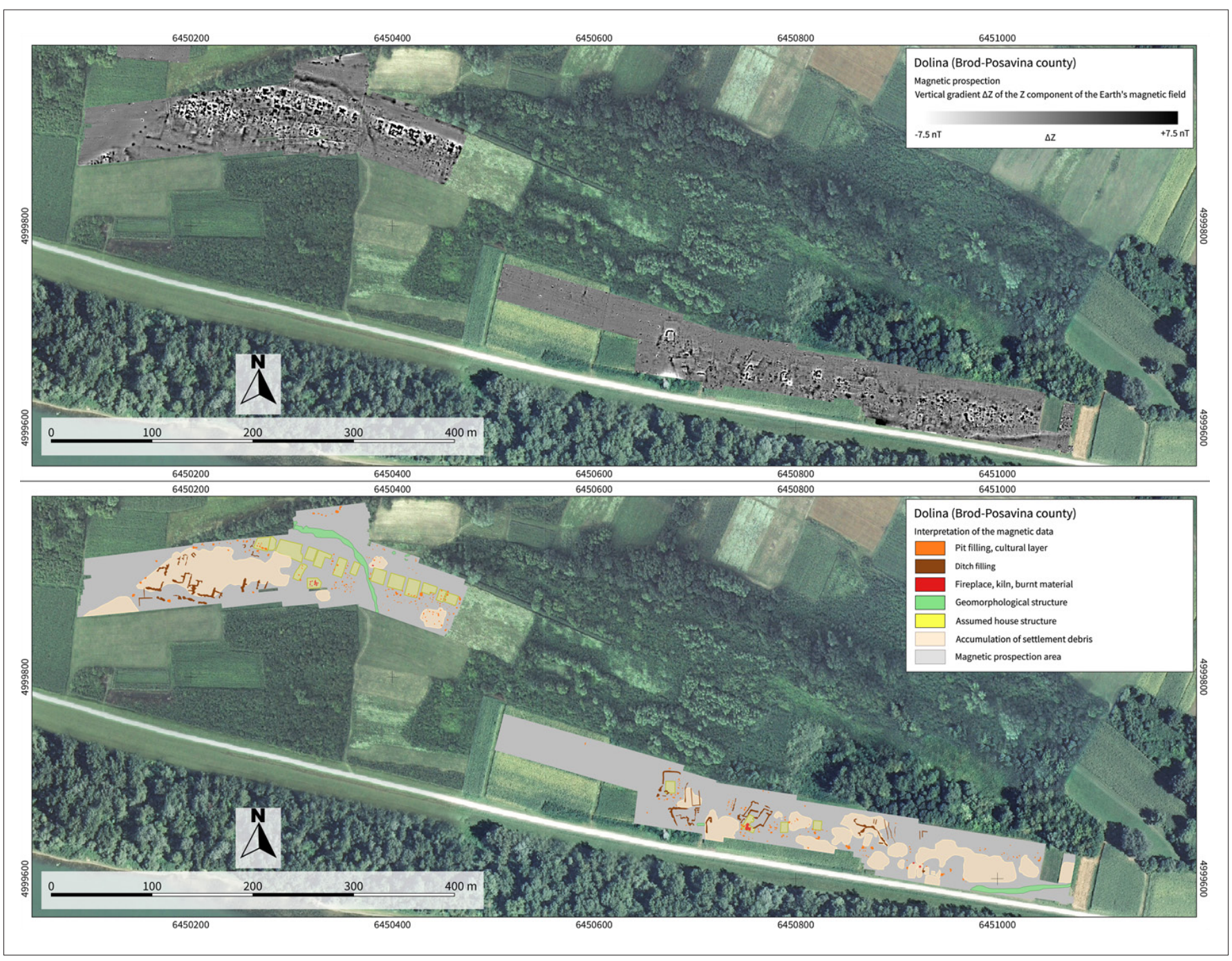

Figure 5. Dolina - Late Bronze Age and Early Iron Age settlement: Magnetic data and archaeological interpretation (Coordinate system: MGI 1901 Balkans Zone 6, EPSG: 3908, orthophoto: geoportal.dgu.hr). 
type is characterised by oxygen deficiency and high clay content and offers satisfactory conditions for magnetic investigations at archaeological sites.

At Dolina several archaeological structures are already known, e.g. the Glavičice tumuli group consisting of at least 15 tumuli and the assumed flat grave necropolis of Draganje. In the general archaeological context, the site dates to the Late Bronze Age and the Early Iron Age. However, the settlement associated to the necropoleis is hitherto testified only by numerous surface finds mainly dated between 11th and 7th centuries BC (Ložnjak Dizdar et al. 2010; 2011). The site has been subjected to intensive archaeological investigations since 2009.

The principal aim of the magnetic survey was to enlighten the spatial relationship of the contemporaneous settlement and the cemetery. Up to the magnetic survey campaign, the settlement associated with the tumuli at the position of Glavičice had been located only through field surveys. Its assumed location is on the first elevated plateau next to the Sava River. The distribution of the surface finds suggests that the settlement stretches in the east-west direction over a surface of more than half a hectare (Ložnjak Dizdar and Gavranović 2014).

The buried structures of both, the cemetery and the settlement present favourable conditions for a magnetic survey. High amplitudes of remanent magnetisation can be expected at accumulations of burnt material as to be found in the burials. Prehistoric settlements may comprise remains of collapsed houses built of wood and daub as well as fillings of ditches and pits. Furthermore, remains of kilns and fireplaces cause distinct and strong magnetic anomalies in many cases. These anomalies arise from the thermoremanent magnetisation of the repeatedly burnt materials.

The results of the magnetic survey allowed several conclusions. To the south of the necropolis of Glavičice, an area has been located where remains of human settlement are expected. The populated area is situated on a long, slightly elevated terrain and shows a clear division into three parts from north to south: In the northern part, clearly distinguishable anomalies in almost rectangular clusters probably indicate well-preserved remains of houses or other settlement structures. The structures are characterized by strong magnetic anomalies, which indicate thermoremanently magnetized material, such as fired clay and baking clay. Those are aligned along a WNW-ESE oriented line and have similar dimensions. The central part of the presumed settlement to the south is less clearly defined. Nevertheless, magnetic anomalies indicate the presence of pits, furnace remains and postholes, and in the southern part dominate linear anomalies caused by a system of filled ditches. The total of the populated area could not be accurately determined due to the limitation of the surveyed fields caused by modern agricultural activity. However, it is assumed that the settlement covered between 3 and 5 ha (Fig. 5). Archaeological excavations, based on the magnetic data, has started in 2015 and revealed an even more complex stratigraphic sequence consisting of layers of burnt clay overlaying filled pits of the older house remains (Ložnjak Dizdar et al. 2017).

\section{The Neolithic site of Gorjani-Kremenjača (Osijek- Baranja county)}

Starting in October of 2018 a large-scale magnetic survey has been realised at the Neolithic site of Kremenjača (Osijek-Baranja county). The objective of the surveys was to investigate the surroundings of an assumed ring ditch system. In contrast to other Neolithic 'ditch sites' in Slavonia, the system at Gorjani is not visible in aerial photographs (Šiljeg and Kalafatić 2016). So far, the investigated area sums up to a total of about 20 ha at the site of Kremenjača.

The site is situated in the geological formations of the Pannonian Basin. The central Đakovo-Vinkovci plateau together with the Vukovar plateau were formed along regional faults, and are covered by Quaternary deposits. The survey area, situated on the gentle slopes are shaped by alluvial sedimentation processes.

The majority of the Neolithic settlements in Slavonia belong to the Starčevo (earlier Neolithic) and the Sopot (later Neolithic) cultures. In general, the layout of these settlements is diverse and complex and still subject of investigation.

After first, unpublished geophysical surveys on a limited area, first test excavations were carried out in 2015 and 2016. From the four trial trenches, opened at the top of the Kremenjača hillock, the material found there was dated to an age of 5,000 BC and since then archaeological excavations have continued.

The magnetic data, obtained in 2018 and 2019 already provided a substantial contribution to the overall understanding of the prehistoric complex. The data indicate a multi-layered stratigraphy of prehistoric settlements 
which corresponds to the surface finds. Several complex ditch systems are recognised. Figure 6 shows the status of the magnetic survey and data interpretation from the end of 2018. In the southern and central part, two complex ring ditch systems are observed with axis lengths of about $150 \mathrm{~m}$. With the two outer ditch systems with estimated diameters of 400 and $500 \mathrm{~m}$, respectively, the ring structure can still only be assumed. The density of prehistoric structures decreases from the centre of the site toward the outer limits. The highest densities of structures are observed inside the ring ditch systems and in the north between the central ring ditch and the intermediate ditch. The geophysical data and their interpretation are a very suitable base for archaeological classification in the context of the development of Neolithic settlements in Slavonia (Šošić Klindžić et al. 2019).

\section{The necropoleis of Gradac and Sredno in Batina (Osijek-Baranja county)}

In October of 2016, a magnetic prospection was realised at the archaeological sites of Gradac and Sredno in Batina, located on the loess ridge of Bansko brdo, in the Municipality of Draž (Osijek-Baranja county). The objective of the investigation was to identify prehistoric and Roman settlement remains as well as burials of the already known prehistoric and Roman cemetery at the Sredno site. Geology and soils of the area are characterised by Pleistocene sediments of the southern Pannonian Basin. The sites of Batina lay over a plateau composed of loess deposits intercalated by poorly developed palaeosols which accumulated during the Middle and Late Pleistocene forming the northeastern edge of the Bansko

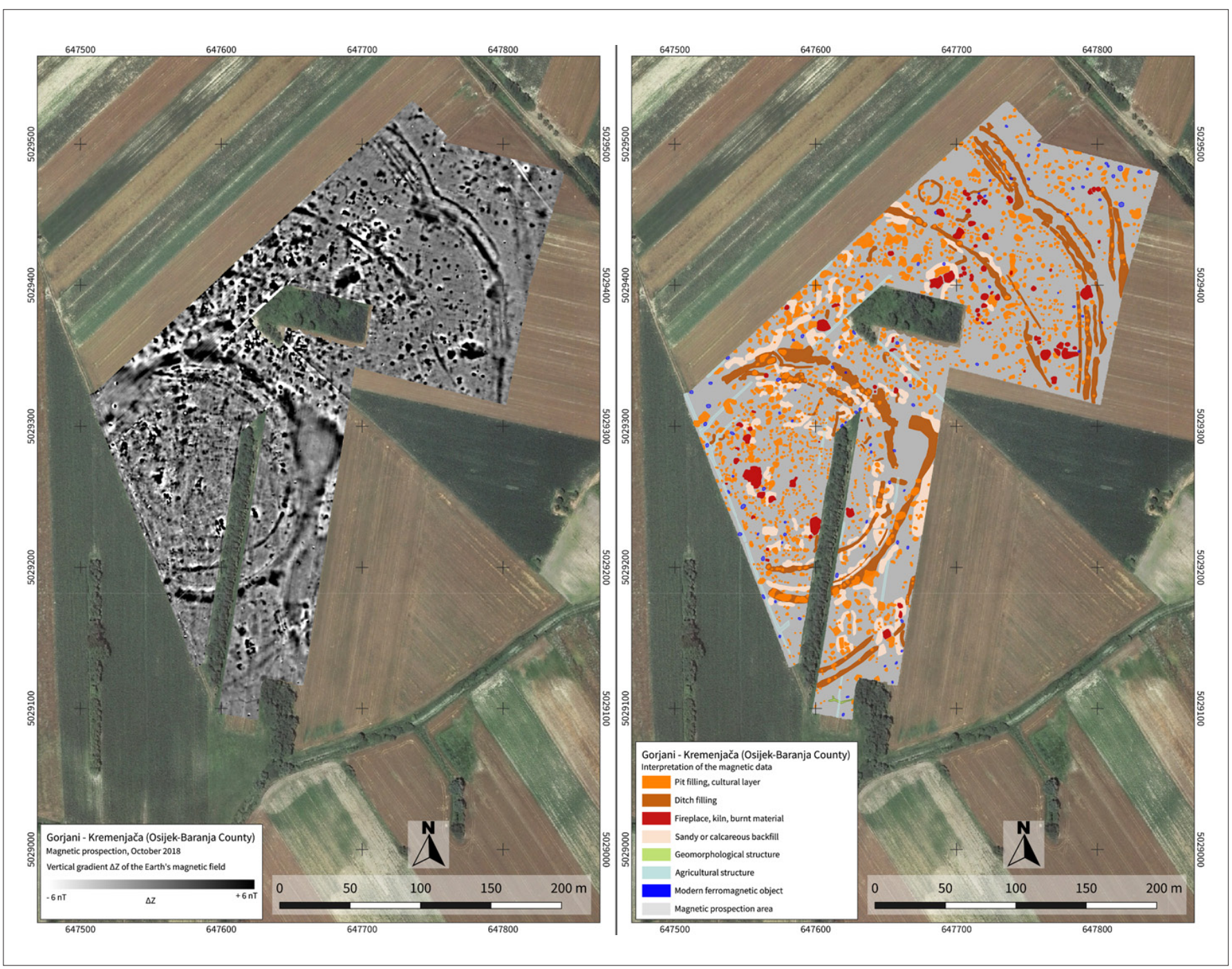

Figure 6. Gorjani - Kremenjača: Magnetic data and archaeological interpretation (Coordinate system: HTRS96 Croatia TM, EPSG:3765, orthophoto: geoportal.dgu.hr). 


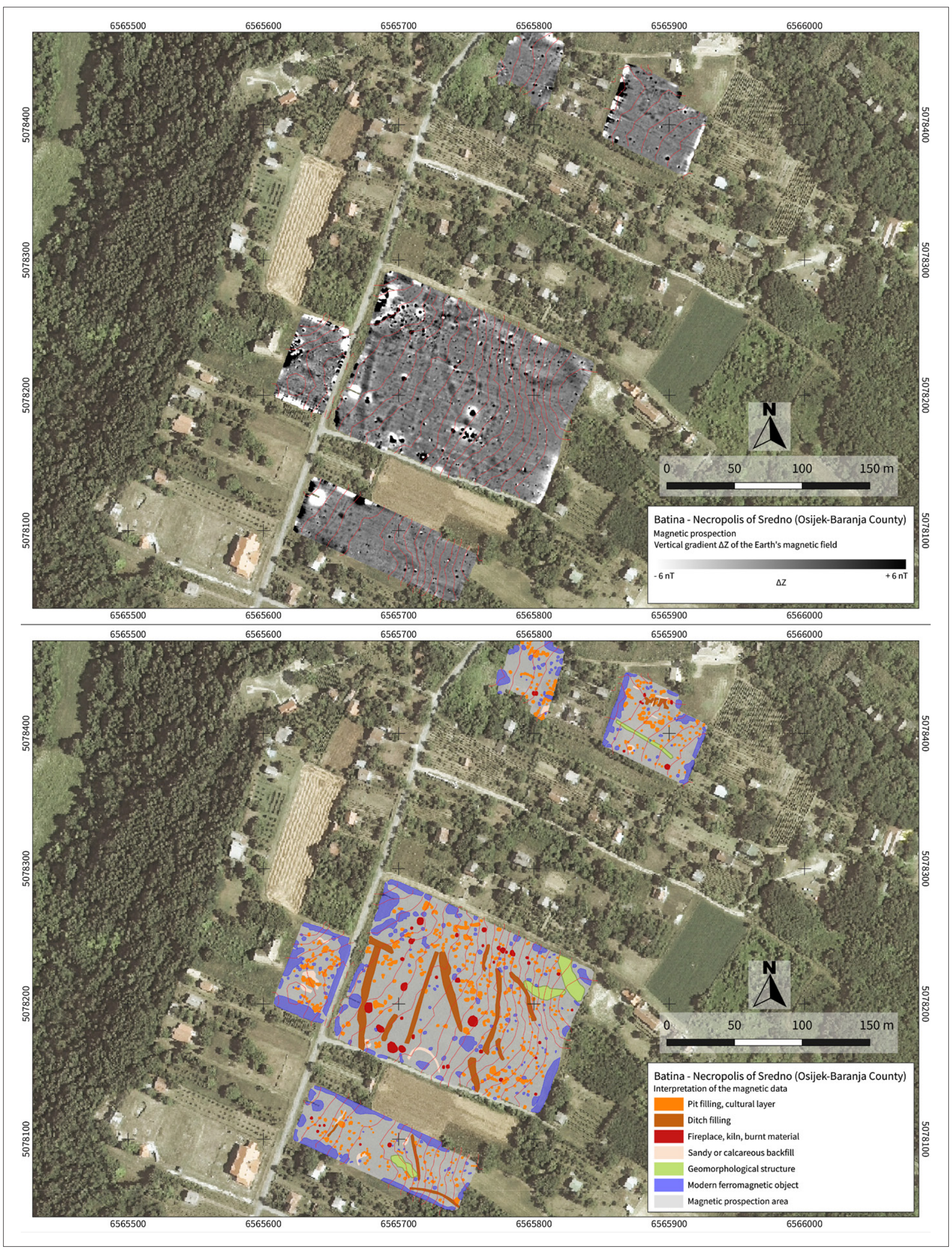

Figure 7. Batina - Necropolis of Sredno: Magnetic data and archaeological interpretation (Coordinate system: MGI Balkans zone 6, EPSG: 31276, orthophoto: geoportal.dgu.hr). 
brdo. In addition to thick Pleistocene loess layers and deposits of volcanic rock, the slopes of the plateau, especially on the western and northern edges also reveal Miocene limestone and marl with igneous clastics (Velić and Vlahović 2009).

The important prehistoric and Roman sites of Batina have been subjected to archaeological investigations since 2010. The main focus has been on the Late Bronze and Iron Age settlement and cemeteries. However, the earliest evidence from human activity date back to the Neolithic (6th millennium BC). The long sequence of permanent occupation is expressed in cultural layers up to $6 \mathrm{~m}$ thick with rich archaeological finds like fragments of ceramic vessels, stone and metal tools, jewellery and weapons.

Already in 2008, fragments of ceramic vessels and burnt human bones were found during field surveys, pointing to the existence of a cemetery at the site of Sredno. Consequently, remains of burial mounds (tumuli) were discovered, dating to the beginning of the Iron Age (8th century $\mathrm{BC}$ ). The tumuli contained incineration remains in ceramic vessels or in organic envelopes. So far, 61 graves from the Late Bronze Age and the Iron Age were located and partly excavated. Besides those burials, several ditches varying in width and depth were found (Bojčić et al. 2009; 2010; 2011; Hršak et al. 2013; 2014; 2015; 2016; 2017; 2018).

Of importance for local archaeological research, is also the fact that in November 1944 the Battle of Batina, one of the largest battles of World War II, took place here. It can be taken for granted that the combat operations, involving several tens of thousands of soldiers, left significant marks in the ground.

Magnetic measurements were executed on an area of approximately 3.6 ha. Despite the proximity of modern buildings and the impact of WWII, the data quality allowed for a detailed interpretation of the geophysical data (Fig. 7). The magnetic data from the cemetery site of Sredno revealed numerous archaeological features. Firstly, several clusters of incineration burials were identified, and secondly, the data gave some weak indications of the existence of flattened tumuli. Furthermore, the magnetic data showed a complex network of filled ditches in the southern part of the investigated cemetery site, confirming findings from previous archaeological excavations. Subsequent excavations revealed several new incineration graves in very good coincidence with the magnetic data interpretation, However, also burials of a fallen soldier of the Batina battle were discovered (Hršak et al. 2018).

\section{A burial mound near Stari Jankovci (Vukovar-Sri- jem county)}

The archaeological site of Stari Jankovci is located east of Vinkovci (Vukovar-Srijem county). It consists of at least four tumuli, of which three are known and located inside the forest. They are up to 8 meters high. For a long time, their context and place in time have been unknown. The fourth and already flattened tumulus lies outside of the forest and is recognised as a smaller elevation in the flat terrain.

This tumulus and its immediate surroundings were subjected to magnetic measurements on an area of about 0.5 ha. The archaeological interpretation of the magnetic data is hindered on the western side by numerous groups of strong dipole anomalies reflecting modern deposits. However, the data obtained from the area of the tumulus itself allow a detailed interpretation (Fig. 8). Two very strong circular dipole anomalies stand out in the centre of that structure. They probably reflect a large accumulation of burnt material and ferromagnetic objects, pointing to major incineration burials. Around the two dipoles, linear positive anomalies reflect earthen features which refer to the construction of the mounds. Also, in association to these anomalies, smaller linear negative anomalies are visible and reflect stone settings, probably from diamagnetic sandstone. Recent archaeological excavations revealed a two-wheeled Roman chariot with the fossilised remains of two horses in a large burial chamber (Fig. 8). The finding corresponds with one of the large dipole anomalies. Thus, the dipole anomalies originate in the strong magnetisation of iron parts of the chariot and the horses' harnesses as well as from the burnt material associated with the burial. 


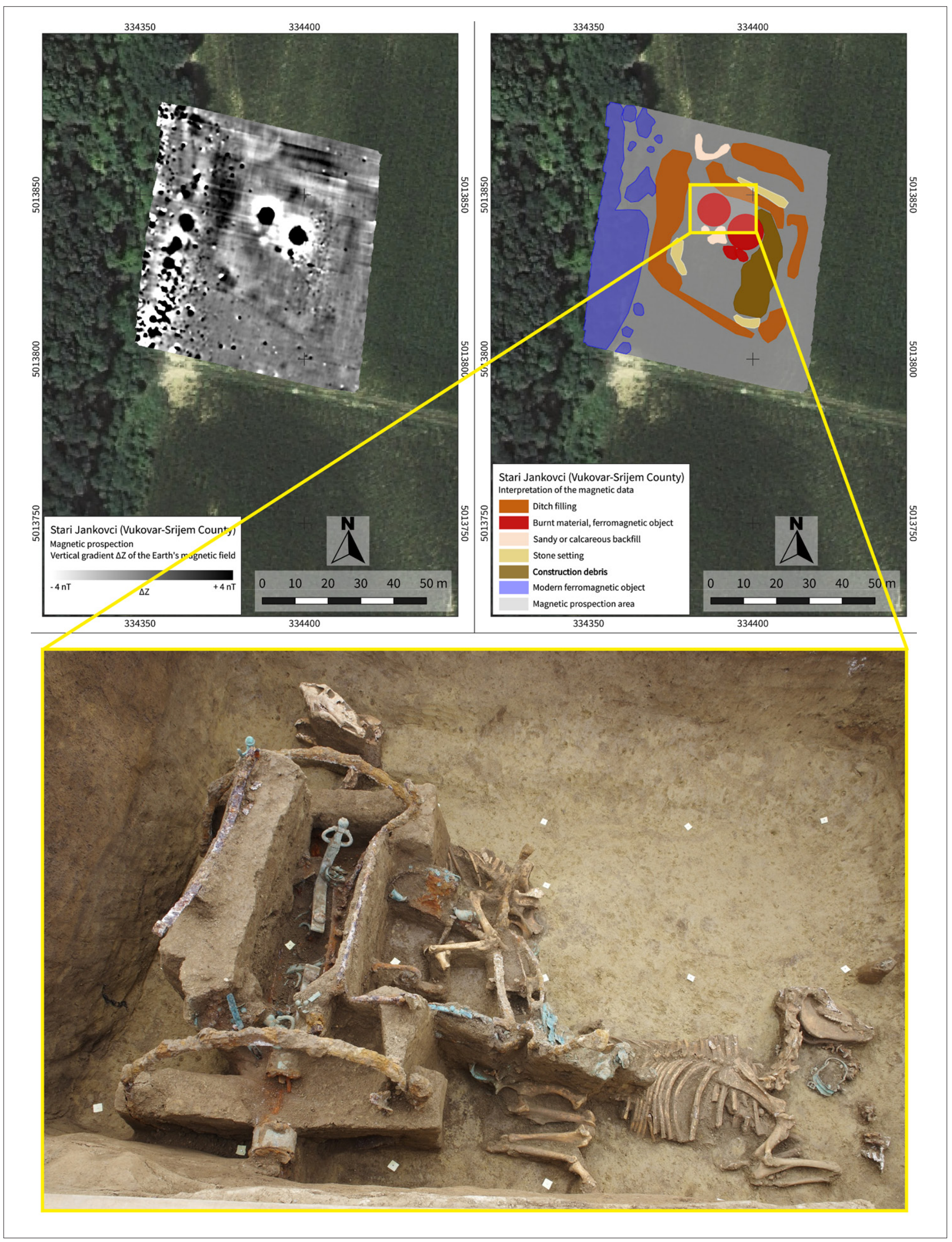

Figure 8. Tumulus near Stari Jankovci: Magnetic data, archaeological interpretation and a photograph of the Roman chariot, excavated in 2019 (Coordinate system: ETRS89 UTM zone 34N, EPSG: 25834, orthophoto: geoportal.dgu.hr, photograph: Boris Kratofil). 


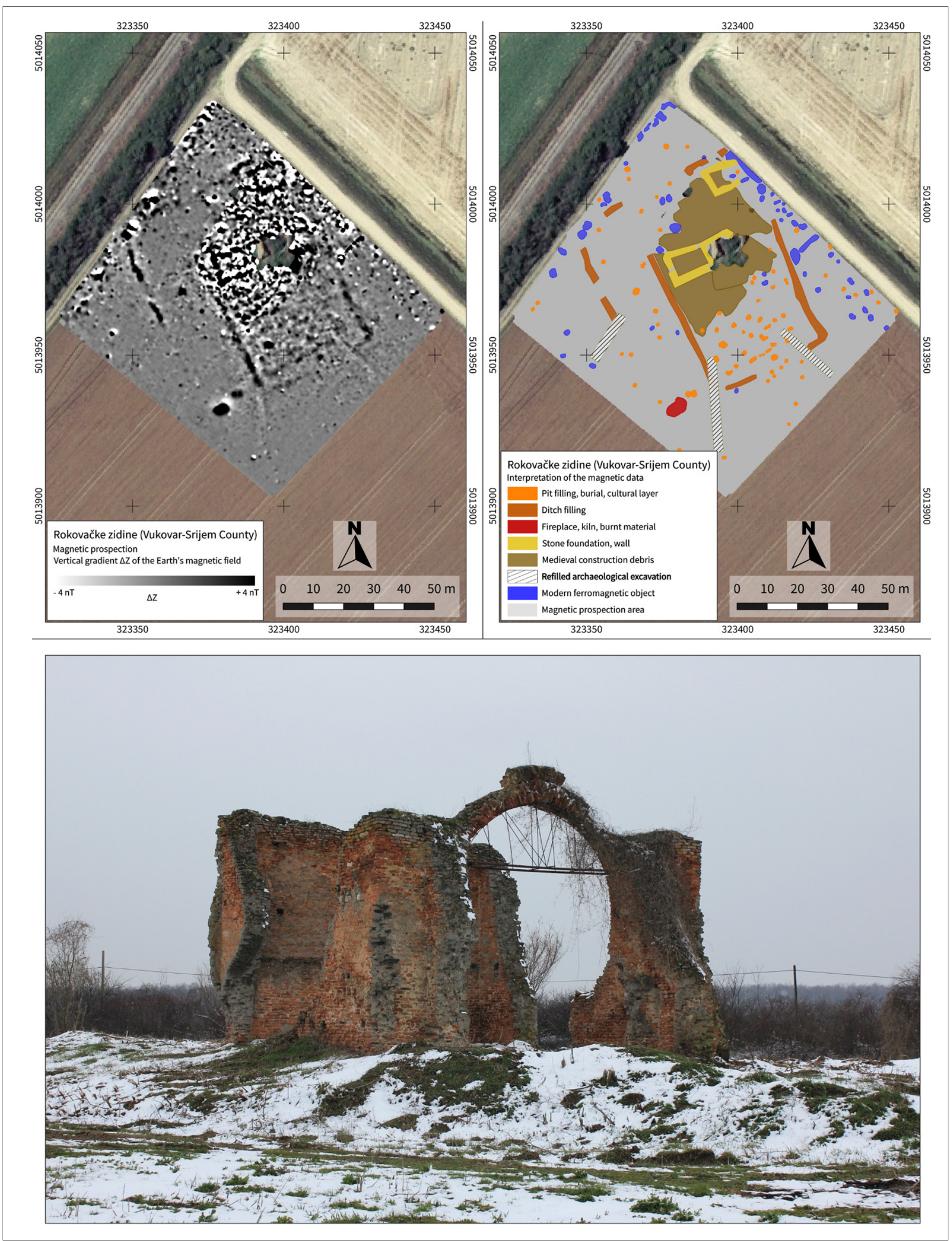

Figure 9. Rokovačke zidine: Magnetic data, archaeological interpretation and terrain conditions at the church's ruins (Coordinate system: ETRS89 UTM zone 34N, EPSG: 25834, orthophoto: geoportal.dgu.hr, photograph: Cornelius Meyer). 


\section{The medieval site of Rokovačke zidine (Vukovar- Srijem county)}

In March of 2018, a magnetic survey was realised on the medieval site of Rokovačke zidine near Rokovci (Vukovar-Srijem county). Based on historical sources and prior archaeological research, the site was identified as a $15^{\text {th }}$-century church, that most probably was part of a Franciscan monastery (Petković and Rapan Papeša 2011).

The investigated site is located a few kilometres to the south of Vinkovci. The landscape of the region is shaped by the Bosut river. Numerous archaeological sites in the surroundings of Vinkovci are concentrated along the meandering and slowly flowing river. In the middle of the completely flat fields between Vinkovci and Rokovci, the ruined walls of the medieval church called Rokovačke zidine, rise up. There has been much debate about the age and function of the building. It is assumed that the surviving walls date back to the $15^{\text {th }}$ century and that they belonged to a Franciscan monastery founded at a place of a previous medieval village (Petković and Rapan Papeša 2011). The remains of the church are composed of baked bricks and ashlar. Those rise out of a slightly elevated plateau with a surface of not more than $2.000 \mathrm{~m}^{2}$. It is reasonable to assume that the plateau consists essentially of the debris of the church and its no longer visible adjacent buildings.

In order to obtain information on adjacent buildings and the spatial organization of the monastic complex, the magnetic array LEA MAX was used to investigate a total surface of approximately 0.9 ha. The gradiometer system was set up with respectively, 10 and 7 fluxgate gradiometer probes. Depending on the different surface conditions on the site, it was either moved on wheels or carried by hand. The obtained data indicate the existence of a ditch forming a rectangular enclosure of the religious complex. Furthermore, the ground plans of two adjacent buildings were identified. Numerous pits, found in the area to the south of the church, suggest the existence of a necropolis (Fig. 9).

\section{Conclusion}

Measured by effort and benefit, the systematic investigation of archaeological sites with geophysical methods is a highly effective tool. The archaeological record and the natural conditions found in large parts of Northern and Eastern Croatia favour the application of the magnetic prospection as primary investigation method. Thanks to the development of light-weight and flexible magnetometer arrays, the survey of large areas in a short time is possible. Using human power to drive the equipment daily outputs of up to 6 hectares are achievable. The productivity can be increased by using ATVs for pulling the magnetometer arrays. In this manner, daily surveys of 25 hectares are feasible, given favourable surface conditions. However, the typical small plot sizes of the region and the requirements of field owners and tenants often impede the use of motorised vehicles, which may cause considerable damage to fields and crops.

The value of geophysical surveys can further be enhanced by the application of more than one method. In the case of urban surveys and investigations of Roman and medieval sites, the GPR can yield complementary results which can support the process of data interpretation. Geoelectrical and GPR measurements are also recommended at the investigation of complex sites such as burial mounds or multi-phase settlements. In contrast to magnetic surveys, geoelectrical and GPR data allow to determine the depth of located structures with sufficient precision. However, typical alluvial soils of Slavonia are less suitable for georadar investigations due to their high clay content and the resulting strong attenuation of the electromagnetic waves.

Besides the advanced equipment and the consideration of the environmental conditions, the simple truth is that the value of a geophysical survey is essentially determined by the quality of data processing and interpretation. Only with a detailed analysis, which must also include a consideration of its reliability, geophysical data can be used to plan excavations or protective measures at threatened monuments. Therefore, it must be emphasized again that geophysical data cannot provide a direct image of ground structures, even if the interpretation drawings sometimes suggest this, but only open small information windows to the structures in the subsoil that refer to the respective geophysical parameter recorded. 


\section{Acknowledgements}

The authors want to express their sincere thanks to all authorities, especially the Institute of Archaeology in Zagreb, the Department of Archaeology at the Faculty of Humanities and Social Sciences of the University of Zagreb, the Museum of Vinkovci, the Municipality of Andrijaševci, the Museum of Nova Gradiška and the Archaeological Museum of Osijek for funding, permissions, and support. Their engagement also included fruitful discussions on the data interpretation and plausibility considerations.

We warmly thank all members of the teams realising the measurements on the archaeological sites: Margherita Carletti, Lise Goossens, Wioleta Hypiak, Dana Pilz, Agnes Schneider, Pedro Gonçalves, Ekkehard Schönherr, and Henning Zöllner. Further thanks go to Ronald Freibothe (Eastern Atlas GmbH \& Co. KG, Berlin) for his engagement in the data processing. Moreover, the magnetic measuring equipment was developed and provided by Eastern Atlas. 


\section{References}

Aitken, M. J. 1970. Magnetic prospecting, Scientific methods in medieval archaeology, Berkeley - Los Angeles - Londres, 423-434.

Bojčić, Z., Dizdar M., Hršak, T. and Leleković, T. 2009. Terenski pregled područja Batine (Field Survey of the Batina Area), Annales Instituti archaeologici V, 125-129.

Bojčić, Z., Dizdar, M., Hršak, T., Vukmanić, I., Dujmić, D. and Leleković T. 2010. Terenski pregled područja između Batine i Suze (Field Survey of the Area between Batina and Suza), Annales Instituti archaeologici VI, 80-87.

Bojčić, Z., Dizdar, M., Hršak, T. and Leleković T. 2011. Rezultati probnih istraživanja nalazišta Batina Sredno 2010 (Results of the 2010 Trial Excavations of the Batina - Sredno Site), Annales Instituti archaeologici VII, 13-19.

Botić, K. 2017. Preliminary results of geophysical research and geological sampling of eastern Slavonian sites in 2016, Annales Instituti Archaeologici XIII, 141-151.

Conyers, L. B. 2012. Interpreting Ground-penetrating Radar for Archaeology, Left Coast Press, Walnut Creek.

Fassbinder, J. W. 2017. Magnetometry for archaeology, In: E. Gilbert (ed.), Encyclopedia of Geoarchaeology, Encycl. Earth Sci. Series, 499-514.

Fassbinder, J. W. 2015. Seeing beneath the farmland, steppe and desert soil: magnetic prospecting and soil magnetism, Journal of Archaeological Science 56, 85-95.

Hršak, T., Leleković, T. and Dizdar, M. 2013. Rezultati istraživanja nalazišta Batina - Sredno 2012. godine, Annales Instituti Archaeologici IX, 12-19.

Hršak, T., Leleković, T. and Dizdar, M. 2014. Rezultati istraživanja nalazišta Batina - Sredno 2013. godine, Annales Instituti Archaeologici X, 14-20.

Hršak, T., Leleković, T., Dizdar, M. 2015. Rezultati istraživanja nalazišta Batina - Sredno 2014. godine, Annales Instituti Archaeologici XI, 18-22.

Hršak, T., Leleković, T. and Dizdar, M. 2016. Rezultati istraživanja nalazišta Batina - Sredno 2015. godine, Annales Instituti Archaeologici XII, 14-18.

Hršak, T., Leleković, T. and Dizdar, M. 2017. Rezultati istraživanja nalazišta Batina - Sredno 2016. godine, Annales Instituti Archaeologici XIII 40-45

Hršak, T., Leleković, T. and Dizdar, M. 2018. Preliminarni rezultati arheoložkoga istraživanja u Batini 2016. godine, Annales Instituti Archaeologici XIV, 34-39.

Jones, G. and Maki, D. L. 2005. Lightning-induced magnetic anomalies on archaeological sites, Archaeological Prospection 12 (3), 191-197.
Kovačević, S. 2018. Arheološko istraživanje prapovijesnog lokaliteta Jalžabet - Bistričak u 2017. godini i Kamp Hrvatska projekta "Iron-Age-Danube" INTERREG DTP, Annales Instituti Archaeologici XIV, 1, 72-75.

Linford, N. T. and Canti, M. G. 2001. Geophysical evidence for fires in antiquity: preliminary results from an experimental study, Archaeological Prospection 8 (4), 211-225.

Ložnjak Dizdar D. and Gavranović, M. 2014. Across the River. The Cemetery in Dolina and New Aspects of the Late Urnfeld Culture in Croatian Posavina and Northern Bosnia, Archaeologia Austriaca 97/98, 13-32.

Ložnjak Dizdar D., Mihaljević, M. and Dizdar, M. 2011. Dolina 2010. - rezultati probnih istraživanja prapovijesnog groblja Glavičice, Annales Instituti Archaeologici VII, 4144.

Ložnjak Dizdar D., Mihaljević M. and Dizdar, M. 2010. Rezultati pokusnog istraživanja prapovijesnog groblja Glavičice i Draganje u Dolini 2009, Annales Instituti Archaeologici VI, 41-46.

Ložnjak Dizdar, D., Mihaljević, M., Dizdar, M. and Gavranović, M. 2017. Dolina-Babine Grede-istraživanje kasnobrončanodobnoga naselja u Posavini 2016. godine, Annales Instituti Archaeologici XIII, 57-63.

Meyer, C. 2013. Interpretation and Guidelines for Reporting. In: C. Corsi, B. Slapšak and F. Vermeulen. (eds.), Good Practice in Archaeological Diagnostics, Springer, Cham, 177-190.

Mušič, B. and Horn, B. 2019. Archaeological geophysics Introduction. In: Z. Czajlik, M. Črešnar, M. Doneus, M. Fera, A. Hellmuth-Kramberger and M. Mele (eds.), Researching archaeological landscapes across borders - Strategies, methods and decisions for the 21st century, Archaeolingua, Graz - Budapest, 108-112.

Mušič, B., Vukmanić, I., Medarič, I., Mori, M., and Nas, E. 2013. Geophysical surveys of Roman forts built along the Danube Limes in Croatia, Geološki zbornik 22, 106-109.

Neubauer, W. and Eder-Hinterleitner, A. 1997. 3D-interpretation of postprocessed archaeological magnetic prospection data, Archaeological Prospection 4 (4), 191-205.

Petković, D. and Rapan Papeša, A. 2011. Rokovačke zidine, Acta Musei Cibalensis, Nova serija, 4, Gradski muzej Vinkovci, Vinkovci.

Schmidt, A. 2009. Electrical and magnetic methods in archaeological prospection, In: S. Campana and S. Piro (eds.), Seeing the unseen. Geophysics and Landscape Archaeology, Taylor \& Francis Group, London, 67-82. 
Sekelj Ivančan, T. and Mušič, B. 2014. Geofizička i arheološka istraživanja na nalazištu Virje: talionička radionica iz vremena kasne antike i ranog srednjeg vijeka, Starohrvatska prosvjeta 3 (41), 177-183.

Šiljeg, B and Kalafatić, H. 2016. Zračno rekognosciranje, Osječko-Baranjska županija, Aerial Archaeology XII, 213222.

Šimek, M. 1998. Ein Grabhügel mit Pferdebestattung bei Jalžabet, Kroatien, In: B. Hänsel and J. Machnik (eds.), Das Karpatenbecken und die osteuropäische Steppe, Südosteuropa-Schriften 20; Prähistorische Archäologie in Südosteuropa 12, München, 493-510.

Šimek, M. and Kovačević, S. 2014. Jalžabet - Bistričak: On the eve of the new research, Prilozi Instituta za arheologiju u Zagrebu 31 (1), 231-238.

Šošić Klindžić, R., Kalafatić, H., Šiljeg, B. and Hršak, T. 2019. Krugovi i keramika kroz stoljeća: značajke naselja sopotske kulture, Prilozi Instituta za arheologiju u Zagrebu 36, 4184.
Velić, I. and Vlahović, I. 2009. Geological map of the Republic of Croatia 1: 300.000, Croatian geological institute, Zagreb.

Vidaček Z., Husnjak, S. and Bensa, A. 2001. Specific hydropedological characteristic of the Sava river catchment, Zbor. Rad. Hidrologija i vodni resursi Save u novim uvjetima, Slavonski Brod, 403-416.

Zöllner, H., Kniess, R., Meyer, C. and Trinks, I. 2011. Efficient large-scale magnetic prospection using multi-channel fluxgate arrays and the new digitizer LEA D2. In: M. G. Drahor and M. A. Berge (eds.), Archaeological Prospection 9th International Conference, Archaeology and Art Publications, Izmir, Turkey, 21-23. 